\title{
Youth centres in Ghana: Assessment of the Planned Parenthood Association of Ghana Programme
}

\author{
Evam Kofi Glover \\ Annabel Erulkar \\ Population Council \\ Joana Nerquaye-Tetteh
}

Follow this and additional works at: https://knowledgecommons.popcouncil.org/departments_sbsr-rh

Part of the Demography, Population, and Ecology Commons, Health Services Research Commons, International Public Health Commons, and the Public Health Education and Promotion Commons How does access to this work benefit you? Let us know!

\section{Recommended Citation}

Glover, Evam Kofi, Annabel Erulkar, and Joana Nerquaye-Tetteh. 1998. "Youth centres in Ghana: Assessment of the Planned Parenthood Association of Ghana Programme," Africa OR/TA Project II Final Report. Nairobi: Population Council. 


\section{YOUTH CENTRES}

IN

\section{GHANA}

\section{ASSESSMENT OF THE \\ PLANNED PARENTHOOD ASSOCIATION OF GHANA PROGRAMME}

Evam Kofi Glover, Planned Parenthood Association of Ghana Annabel S. Erulkar, The Population Council

Joana Nerquaye-Tetteh, Planned Parenthood Association of Ghana

October, 1998

\section{(2) Population Council}




\section{(1) Population Council}

The Population Council seeks to improve the wellbeing and reproductive health of current and future generations around the world and to help achieve a humane, equitable, and sustainable balance between people and resources. The Council, a nonprofit, non-governmental organization established in 1952, has a multinational board of trustees; its New York headquarters supports a global network of regional and country offices.

Population Council

Multichoice towers

Upper Hill

P.O. Box 17643

Nairobi, Kenya

Tel: (254) 2-713480/1/2/3

Fax: (254) 2-713479

e-mail: pcnairobi@popcouncil.org

Population Council

One Dag Hammarskjold Plaza

New York, NY 10017 USA

Tel: (212) 339-0500

Fax: (212) 755-6052

e-mail: pubinfo@popcouncil.org

http://www.popcouncil.org

The Planned Parenthood Association of Ghana provides couples and individuals with the knowledge and means of exercising their basic human rights to decide freely and responsibly on their reproductive health as one of the means of improving quality of life of Ghanaians. The mission objectives are:

1. To assist national efforts aimed at improving the socio-economic and political life of the population.

2. To promote the physical and mental health of families especially children, through better spacing of births.

3. To initiate and promote education and other programmes aimed at responsible family life for adults and youth.

Planned Parenthood Association of Ghana

P.O. Box 5756

Accra, GHANA

Tel: (233) 21-304567 / 310369

Fax: (233) 21-304567

e-mail: ppag@africaonline.com.gh

(C) The Population Council, Inc. 


\section{TABLE OF CONTENTS}

\section{Acknowledgements}

Abbreviations

List of Tables and Figures

Executive Summary

I. INTRODUCTION

II. OBJECTIVES OF THE ASSESSMENT

III. STUDY DESIGN AND METHODOLOGY

IV. BACKGROUND: THE PPAG YOUTH CENTRES

V. SAMPLE

VI. RESULTS
A Youth Centre Facilities
Services Offered at the Youth Centres
Privacy and Anonymity
Accessibility and Availability of Services
Management Information Systems (MIS)
Community Involvement

B. Youth Centre Staff and Volunteers

Personnel Structure and Training

Reproductive Health Knowledge

Opinions and Practices

Counselling Skills

C. Youth Centre Clients

Profile of Youth Centre Clients

Reasons for Visiting the Youth Centres

Reproductive Health Knowledge of Youth at the Centres

D. Utilization of Youth Centre Clinic

VII. RECOMMENDATIONS

Appendix I: Counselling Case Records 


\section{ACKNOWLEDGEMENTS}

First and foremost, we would like to acknowledge Dr. Bob Miller of the Population Council, New York, who has provided enormous encouragement and guidance in this and other youth projects. We thank Alex Amankwah-Poku of PPAG who provided support in processing of the data. PPAG Area Managers and staff from the youth centres were a pleasure to work with on this study and we are grateful for their cooperation and hospitality. In particular we thank the young people themselves, those that we met at the youth centres and beyond, for agreeing to share their time and ideas with us.

\section{ABBREVIATIONS}

$\begin{array}{ll}\text { AIDS } & \text { Acquired Immune Deficiency Syndrome } \\ \text { FLE } & \text { Family Life Education } \\ \text { FP } & \text { Family Planning } \\ \text { FPA } & \text { Family Planning Associations } \\ \text { HIV } & \text { Human Immuno-deficiency Virus } \\ \text { IPPF } & \text { International Planned Parenthood Federation } \\ \text { PPAG } & \text { Planned Parenthood Association of Ghana } \\ \text { MCH } & \text { Maternal and Child Health } \\ \text { MOH } & \text { Ministry of Health } \\ \text { RH } & \text { Reproductive Health } \\ \text { STD } & \text { Sexually Transmitted Disease } \\ \text { USAID } & \text { United States Agency for International Development }\end{array}$

\section{LIST OF TABLES AND GRAPHS}

Table 1: Sample Size for the Assessment

Table 2: Services Offered at the Youth Centres

Table 3: Percentage of Staff/Volunteers with Correct Knowledge on Reproductive Health Issues, $\mathrm{n}=21$

Table 4: Percentage of Staff/Volunteers with Equitable Attitudes on Topics, $n=21$

Figure 1: Clients' Perceptions of the Counselor / Nurse, $n=55$

Figure 2: Clients' Perceptions of the Counseling Session, $n=55$

Table 5: Percentage of Youth Having Visited the Centres for Various Reasons, by Sex of the Client

Table 6: Percentage of Youth with Correct Knowledge on Reproductive Health Issues Figure 3: Youth Centre Clinic Attendance, 1/97 to 9/98

Figure 4: Proportion of Youth Clinic Clients Aged 10 to 24

Figure 5: Distribution of Male and Female Clients at the Youth Clinic, n=974

Figure 6: Distribution of Services Given at the Youth Clinics

Table 7: Average Number of Clients at the Youth Clinics, 1/97 to 9/98 


\section{Executive Summary}

PPAG has been a pioneer in the development of youth projects in Ghana since 1972. Currently, PPAG runs twelve youth centres throughout the country. These centres have focussed on providing youth with reproductive health related information, counseling and $\mathrm{RH} / \mathrm{FP}$ services. Additionally, the centres variously offer some recreational activities, library services, and career counselling. The centres also serve as the focal point and resource base from which outreach and community youth programme activities are developed and carried through.

While PPAG has invested a great deal in the youth centre model, there has not been any systematic assessment of the programme to date. It is with this backdrop that a systematic assessment of the centres was undertaken in nine of the twelve PPAG youth centres in late 1998. The main objective of the study was to assess the overall performance, utilization, and effectiveness of the PPAG youth centres in four regions in Ghana. The assessment used a variety of data sources including interviews with staff and volunteers at the centres, exit interviews with youth centre clients, and retrospective analysis of centre and clinic records.

PPAG's youth centres are well designed and well performing. Most centres offer library services alongside counseling and clinical services. This strategy was an effective means to attract young people to an environment that was neutral and acceptable to their parents. Staff and volunteers were extremely knowledgeable on reproductive health $(\mathrm{RH})$ issues and PPAG had made important efforts to promote partnerships in its youth programmes. Below are the recommendations that arose from this assessment:

- Within the youth centres, separate rooms are necessary for recreational facilities, lecture rooms, library, counseling, and clinical services to ensure privacy. Rooms need to be located in such a way that young people can access counseling and clinic rooms with relative anonymity

- The centres' signboards should be replaced with the youth friendly logo which is currently under development by PPAG. In addition, youth centres should be marketed both in the print and electronic media as youth friendly to encourage greater patronage.

- Hours and days operation should be adapted to the lifestyles of young people. Centres should be open during early evening hours and on weekends. The centres should consider closing during the early morning weekday hours when young people are normally engaged in other activities.

- Centres need to have consistent staff who are available at all times to offer services. Each centre should have at least one full-time community health nurse in addition to the project office of the centre.

- The recordkeeping systems at the centres need to be improved and harmonized At a minimum, centres need separate and integrated records for outreach activities and clinical/counselling activities. Information on clients such as age, sex, marital, and school status should be collected along with the information or service that was rendered. Where possible, the MIS should be computerized. There is need for secretarial equipment such as computers and photocopiers to support these activities. 
- PPAG has made laudable efforts to involve the community and other stakeholders in its youth centre programme. PPAG should continue to promote community involvement and commitment through soliciting for further donations, both in the public and private sector. Additional efforts need to be made to reach out to parents.

- Additional efforts should be made to train or orient volunteers, even if they are simply on attachment for a short period. PPAG relies heavily on volunteers in the programme. While volunteers are not expected to perform counseling, it is likely that youth will approach them as they are relatively accessible.

- Staff and volunteers require further training on counseling and sensitization on gender issues. While staff and volunteers were extremely knowledgeable on $\mathrm{RH}$, they were found to advise, rather than counsel and many were not clear on the issue of confidentiality. $\mathrm{h}$ addition, some staff/volunteers held conservative attitudes toward violence against women.

- The youth centres are attracting a good balance of boys and girls within the target age group, 10 to 24 . However, a significant proportion of those coming to the centre for clinical services are out of the target age and the vast majority are female. Only about half of the youth centre clients were aware that counseling and clinical services were available. The centres need to reach out to their existing cliente le to inform them of available services. Also, PPAG needs to ensure that its clinics are not dominated with older clients which defeats the purpose of having a clinic dedicated to youth.

- Youth centres need to intensify RH education to its existing youth centre clients. Clients were found to be seriously deficient in $\mathrm{RH}$ knowledge. The centres need to integrate $\mathrm{RH}$ information in all activities at the youth centres so that, no matter what a young person comes to the youth centres for, he/she leaves with heightened understanding of $\mathrm{RH}$-related issues.

- Facility equipment should be improved or added including IEC equipment and laboratory equipment. 


\section{INTRODUCTION}

The sexual and reproductive health of adolescents has become a major public concern, particularly with the advent of HIV/AIDS. Many organizations have tried to find strategies to reach the youth with reproductive health information and services through various service delivery models. One such model has been the multipurpose youth centre approach. Multi-purpose youth centres typically include recreational or vocational services as entry points for reproductive health $(\mathrm{RH})$ and family planning (FP) information and services that are also available at the centres. There is some evidence in a variety of African settings (notably Kenya and Zimbabwe) suggesting that these centres are underutilized and not cost effective. As a result, the Planned Parenthood Association of Ghana (PPAG) decided to undertake a review of its youth centre programme in order to gauge their effectiveness in reaching young people in Ghana with $\mathrm{RH} / \mathrm{FP}$ information and services.

As a pioneer in the development of youth projects in Ghana PPAG started FLE in schools in 1972 . The advocacy role played by PPAG contributed to the Government of Ghana adopting the family life education (FLE) programme in 1984 as part of the Life Skills syllabus for the Junior Secondary School education. In 1984, PPAG started a youth programme in Akropong, including training of teacher volunteers in giving reproductive information and services to young people, a youth centre located in one of Ghana's prominent teacher training colleges, and another youth centre that doubles as a rehabilitation centre for young unmarried mothers in Abiriw. The programme has expanded through the years. Currently, PPAG runs twelve youth centres throughout Ghana. These centres have focussed on providing both in- and out-of-school youth with reproductive health information, counseling and clinical $\mathrm{RH} / \mathrm{FP}$ services. In the past several years, the mechanism used to give information and motivate clients for services has been through PPAG's project assistants based at these centres as well as, trained peer promoters who work in the communities and refer youth to the centres. Additionally, the centres variously offer some recreational activities, library services, and career counselling. The centres also serve as the focal point and resource base from which outreach and community youth programme activities are developed and carried through.

While PPAG has invested a great deal in the youth centre model, there has not been any systematic assessment of the programme to date. Many questions remain unanswered: who are the beneficiaries of the programme? what are the levels and patterns of patronage of the youth centres? what are the unanswered concerns of youth? are the personnel at these centres well equipped and trained for the role they play? what are the suggestions for improving the centres? what is the cost of services and the implications for sustainability? It is with this backdrop that a systematic assessment of the centres was considered critical. The findings from this research are not only useful to PPAG's youth programme, but are also relevant for other African family planning associations (FPAs) and agencies that are using this model. The lessons learnt from this research will equally be useful to policy makers and government officials whose work entail ensuring the welfare of youth. 


\section{OBJECTIVES OF ASSESSMENT}

The main objective of the study was to assess the overall performance, utilization, and effectiveness of the PPAG youth centres in four regions in Ghana.

The study was specifically designed to:

- Assess the performance of PPAG youth centres vis-à-vis current usage of the centres and number of youth reached, as well as patterns of usage.

- Describe the availability and functioning, and quality of services provided at youth centres.

\section{STUDY DESIGN AND METHODOLOGY}

In all, PPAG has twelve youth centres. For the present study, nine of the twelve PPAG youth centres were assessed. Three youth centres are not included because of time and budgetary constraints. PPAG also has an outreach programme connected to most of the youth centres which includes programmes in schools and other institutions. These activities serve the dual purpose to educate young people where they congregate and also to publicize and refer youth to the centres. This assessment did not review the outreach programme, but only centre-based facilities.

The assessment used an adapted situation analysis methodology. Situation analysis was developed by the Population Council in 1989 as a way of assessing the quality, functioning, and availability of family planning clinics. The method draws upon multiple sources of data, from different levels of service delivery (e.g. the client, the service provider, the facility itself), in order to paint a detailed and nuanced picture of service delivery.

For this assessment, we drew upon seven data sources ${ }^{1}$ :

1) Interviews with all professional staff and volunteers at the youth centres. These self administered questionnaires sought to measure staff/volunteer views of the youth centre, their knowledge of reproductive health, attitudes toward adolescent sexuality and gender issues, as well as their counselling abilities.

2) Exit interviews with clients visiting the youth centres for any reason (both reproductive health and non-reproductive health) over a three day period. Questionnaires with youth centre clients were interviewer administered. Clients' access to the centres, their pattern of utilization, and their views of the counselors were assessed. In addition, client reproductive health knowledge was measured.

3) Retrospective analysis of clinical records (where available) for clients seeing a clinical provider or counselor. Service information was collected including sex and age of the clinic client, the reason for visit and the service given. Records reflect activity from January, 1997 to September, 1998.

4) Attendance of clients that come for any reason to the youth centres over a three day period. Research assistants recorded client movements at the youth centres during opening hours over three consecutive days. Information collected included sex, age, school status, school level of the visitor and the time of the visit.

\footnotetext{
${ }^{1}$ This report does not report on analysis of cost data.
} 
5) Retrospective analysis of Information Education Communication (IEC) activities performed through the youth centre. Activities such as lectures, group discussions, and counselling were reviewed over the past six months.

6) Review of the facilities and equipment Information on hours and days of operation, facilities, staffing structure, and services offered was collected.

7) Cost data from annual reports Data on the cost of youth centre programmes was taken from annual reports over the past three years.

Data for clinical records, IEC activities and counselling was collected from existing records. For some centres, very complete and accurate data were available; for others, data on services and IEC was cursory at best. Analysis was therefore limited by the data that was available. Each centre was visited for three days and it was during this time that interviews with staff and clients and attendance data were collected. Every effort was made to interview every client that came to the youth centre during the three days. However, in some cases this was not possible because of heavy patronage. In these cases, a random sample of clients was interviewed?

Data was entered in EPI-INFO and analyzed either in that package or in SPSS. Qualitative information was transcribed and analyzed.

\section{BACKGROUND: THE PPAG YOUTH CENTRES}

We visited nine youth centres in four regions: Greater Accra, Eastern Region, Ashanti Region and Central Region. Each of the centres offers a constellation of different activities and services. Therefore, the youth centres that were assessed are not exactly comparable. Below is a brief description of each of the centres that are included in this assessment.

\section{Greater Accra Region}

Lartebiokorshie Youth Centre: This is the newest of PPAG's youth centres having been established in July, 1998. The centre is located in Lartebiokorshie, a middle class suburb of Accra and is in the proximity of a cluster of schools which include both primary and junior secondary schools. The centre is also in the vicinity of some major senior secondary schools, such as Accra Academy and Wesley Grammer . Currently, the centre offers library facilities, counseling, and a hotline where young people can phone in and ask questions of a counselor. Young people in need of services are referred to the nearby PPAG clinic while the centre's own clinic is under preparation.

Ayaalolo Youth Centre: Established in 1986, this centre is located in central Accra and is housed in a Ministry of Health facility which is located adjacent to a cluster of primary and junior secondary schools. Currently, the facility is comprised of just one room where counselling services are offered. Young people in need of services are referred to other health facilities. Other rooms within the building are also used by PPAG to conduct recreational and educational activities, though only when they are not being used by the schools or the Ministry of Health.

\footnotetext{
${ }^{2}$ The attendance roster was used as a list of youth centre clients and interviewers selected every nth adolescent for interview, depending on the volume of clients in the centre.
} 


\section{Eastern Region}

Akropong Presbyterian Teacher Training College centre: This centre was established in 1984 in Akropong, a large town in Eastern Region, and is PPAG's first youth centre. The facility is housed on the grounds of the oldest and largest teacher training college in Ghana, which donates the three-room facility, rent-free, to PPAG. The centre offers library services, recreation and a full $\mathrm{RH} / \mathrm{FP}$ clinic on the premises. It is open to both those at the training college and young people from the community.

Mamfe Youth Centre: Mamfe Youth Centre, established in 1996, is located in Mamfe, a small town 5 kilometers from Akropong. The centre targets out-of school young people, especially those involved in trades. The facility is in a small rented and apartment offers in-door games, TV/video, limited library facilities, and clinical RH/FP services.

Abiriw Teens' Centre: Abiriw Teens' Centre was started in 1993 as a rehabilitation programme targeted at unmarried teenage mothers. The centre, located in Ab iriw, a small town 1 kilometre from Akropong, represents a collaboration between the Presbyterian Church, the Ministry of Health, and PPAG. The land and premises for the youth centre has been donated by the Church. Currently the centre offers a three year training course in sewing and baking to unmarried teenage mothers and $\mathrm{RH} / \mathrm{FP}$, and $\mathrm{MCH}$ services available on the premises to both enrollees and other youth.

Adukrom Youth Centre: Founded in July, 1997, the Adukrom Youth Centre is located in the small town of Adukrom, 8 kilometers from Akropong. This is a large facility in a converted residential house which includes library facilities, lecture halls, recreational facilities, RH/FP clinic, and extensive grounds. This is the largest of PPAG's youth centres and targets mainly out-of school youth.

\section{Ashanti Region}

Wesley College Youth Centre This youth centre, founded in 1994 in Kumasi, Ghana's second largest city, represents a collaboration between PPAG and the Methodist Church. The facility is located on the premises of a teachers training college which donated a large room for this purpose. The centre is comprised of one large room where library services are offered in addition to counselling and educational activities.

Teen's Centre Teen's Centre, Kumasi, was founded in 1998. The centre is a small rented facility of three rooms which offers $\mathrm{FP} / \mathrm{RH}$ and $\mathrm{MCH}$ services as well as limited recreational services, mostly in the form of TV/Video. The centre targets unwed teenage mothers, but is also available to other young people both in- and out-ofschool.

\section{Central Region}

Youth Advisory Services (YAS), Cape Coast. Youth Advisory Services (YAS) Centre was established in 1992. The centre is a one-room facility located on the grounds of a Ministry of Health facility that offers MCH/FP services, among others. The room is donated by the Ministry of Health to PPAG. Limited library services, counseling, and non-prescriptive contraceptives are offered.

\section{SAMPLE}

Table 1 displays the sample size for each of the different data sources. 
Table 1: Sample Size for the Assessment

\begin{tabular}{|c|c|c|c|c|c|}
\hline & $\begin{array}{c}\text { INTERVIEW } \\
\text { WITH } \\
\text { CLENTS } \\
\end{array}$ & $\begin{array}{l}\text { INTERVIEW } \\
\text { WITH } \\
\text { STAFF/VOL } \\
\end{array}$ & $\begin{array}{c}\text { CLINIC } \\
\text { RECORDS }\end{array}$ & $\begin{array}{c}\text { IEC } \\
\text { RECORDS }\end{array}$ & $\begin{array}{c}\text { CENTRE } \\
\text { ATTENDANCE }\end{array}$ \\
\hline AYAALOLO & 30 & 5 & - & $3 / 98-9 / 98$ & $9 / 30-10 / 2$ \\
\hline 'LARTEBIOKOSHIE & 35 & 2 & - & $3 / 98-9 / 98$ & $9 / 25,9 / 28-9$ \\
\hline $\begin{array}{l}\text { AKROPONG } \\
\text { TRAINING COLL. }\end{array}$ & 23 & 4 & 1/97-9/98 & $3 / 98-9 / 98$ & $9 / 25,9 / 28-9$ \\
\hline $\begin{array}{l}\text { MAMFE } \\
\text { CENTRE }\end{array}$ & 18 & 1 & 1/97-9/98 & 3/98-9/98 & $9 / 25,9 / 28-9$ \\
\hline ABIRIW & 41 & 0 & $1 / 97-9 / 98$ & $3 / 98-9 / 98$ & $9 / 25,9 / 28-9$ \\
\hline ADUKROM $^{\star \star \star}$ & 39 & 1 & 4/98-9/98 & & 9/30-10/2 \\
\hline WESLEY COLLEGE & 53 & 2 & - & - & $9 / 30-10 / 2$ \\
\hline TEENS CENTRE & 37 & 3 & $5 / 98-9 / 98$ & - & $10 / 5-7$ \\
\hline YAS, CAPE COAST & 15 & 3 & - & - & $10 / 2,10 / 5-6$ \\
\hline TOTAL & 291 & 21 & - & - & - \\
\hline
\end{tabular}

In all, 21 youth centre staff and volunteers - peer promoters and students on attachment - were interviewed. Those interviewed were roughly equally divided between staff $(n=10)$ and volunteers $(n=11)$. Eleven of the staff / volunteers were male while 10 were female. Ages ranged from 21 to 45, with the average age being 30 .

Two hundred and ninety one youth centre clients were interviewed. Clients interviewed were equally divided between boys (51\%) and girls (49\%). Client ages ranged from 9 to 41 years with an average age of 18 . The vast majority (87\%) were unmarried, another $10 \%$ were married or living with a partner, and $3 \%$ were separated, divorced or widowed. Among those that had ever been married or cohabitating, the majority were girls (64\%). Sixty percent of clients were in-school, while $40 \%$ were not. A relatively large proportion $(28 \%)$ of the clients had at least one child, with $80 \%$ of these being female.

\footnotetext{
${ }^{3}$ Generally, youth centre staff within a region rotate between youth centres within the same region. Therefore, within regions, numbers of staff interviewed at the centre reflect the location of interview rather than the youth centre at which they are permanently stationed.
} 


\section{RESULTS}

\section{A Youth Centre Facilities}

Facilities for young people need to be conducive to meet their particular needs. Counseling and clinic facilities need to be sufficiently private and centres need to be accessible to young people, both in terms of hours of operation and distance from home, school or work. Services offered at centres that are multi-purpose should strike a delicate balance in offering alternate activities that are attractive to young people while not overwhelming the intended services and not excluding the intended target.

Services Offered. The nine youth centres offer varying packages of services. Table 2 displays the services offered at the youth centres we visited.

Table 2: Services Offered at the Youth Centres

\begin{tabular}{l|c|c|cc|c|c|c|}
\hline & LIBRARY & $\begin{array}{c}\text { SKILLS } \\
\text { TRAINING }\end{array}$ & $\begin{array}{c}\text { RECREATI } \\
\text { ON }\end{array}$ & $\begin{array}{c}\text { COUNSEL } \\
\text { LING }\end{array}$ & $\begin{array}{c}\text { NON } \\
\text { PRESCRIP } \\
\text { TIVE FP }\end{array}$ & $\begin{array}{c}\text { FP/RH } \\
\text { CLINIC }\end{array}$ & $\begin{array}{c}\text { NONRH } \\
\text { CLINICAL } \\
\text { SERVICE }\end{array}$ \\
\hline AYAALOLO & & & $\checkmark$ & $\checkmark$ & & & \\
\hline LARTEBIOKOSHIE & $\checkmark$ & & $\checkmark$ & $\checkmark$ & & & \\
\hline $\begin{array}{l}\text { AKROPONG } \\
\text { TRAINING COLLEGE }\end{array}$ & $\checkmark$ & & $\checkmark$ & $\checkmark$ & $\checkmark$ & $\checkmark$ & $\checkmark$ \\
\hline $\begin{array}{l}\text { MAMFE YOUTH } \\
\text { CENIRE }\end{array}$ & $\checkmark$ & & $\checkmark$ & $\checkmark$ & $\checkmark$ & $\checkmark$ & $\checkmark$ \\
\hline $\begin{array}{l}\text { ABIRIW TEENS } \\
\text { CENTRE }\end{array}$ & & $\checkmark$ & & $\checkmark$ & $\checkmark$ & $\checkmark$ & $\checkmark$ \\
\hline $\begin{array}{l}\text { ADUKROM YOUTH } \\
\text { CENTRE }\end{array}$ & $\checkmark$ & & $\checkmark$ & $\checkmark$ & $\checkmark$ & $\checkmark$ & $\checkmark$ \\
\hline $\begin{array}{l}\text { WESLEY COLLEGE } \\
\text { YOUTHCENTRE }\end{array}$ & $\checkmark$ & & $\checkmark$ & $\checkmark$ & $\checkmark$ & & \\
\hline $\begin{array}{l}\text { TEENS CENIRE, } \\
\text { KUMASI }\end{array}$ & & & $\checkmark$ & $\checkmark$ & $\checkmark$ & $\checkmark$ & $\checkmark$ \\
\hline \begin{tabular}{l} 
YAS, CAPE COAST \\
\hline
\end{tabular} & $\checkmark$ & & $\checkmark$ & $\checkmark$ & $\checkmark$ & & \\
\hline
\end{tabular}

All of the youth centres offer counseling services and most provide some recreational equipment, primarily in-door games. About half of the youth centres visited offer clinical services on the premises. The remainder refer clients to mainstream PPAG clinics or other facilities. The majority of youth centres have a library, though the scale of the libraries varies form centre to centre.

Library services seems to be an effective mechanism to attract youth to the centres, particularly those that are in-school. Libraries represent a socially acceptable and appealing facility for young people to gather, particularly in the eyes of parents and other gatekeepers. During this assessment, teachers in the region of the Lartebiokorshi centre sent students to the youth centre over the lunch hour, suggesting that schools support and approve of the PPAG centre in that area. Further, previous studies in youth centres have shown that girls tend to prefer educational and skills building activities offered at youth centres, as opposed to

\footnotetext{
${ }^{4}$ Non-prescriptive contraceptives given under special circumstances only.
} 
recreation ${ }^{5}$. Currently, the libraries have books focussing on reproductive health and books targeting in-school youth. The utilization of the libraries by out-of-school youth could be improved by increasing the number of books devoted to business such as accounting, recordkeeping, foreign language, or other skills that would contribute to young people's livelihoods.

A number of the youth centres offer recreational equipment, mostly in the way of indoor games. Studies among Ghanaian youth have shown that they are not as concerned about recreational opportunities as with educational and work opportunities ${ }^{6}$ and, as mentioned, girls are not as attracted by recreation as boys. Centres in Kenya and Zimbabwe that offered recreation as their main strategy to attract youth were dominated by older boys and were unappealing places for adolescent girls to spend their time ${ }^{7}$. While recreational services are attractive, particularly to out-of-school boys, they might not be the best mechanism to draw all types of young people to the centres. Such centres risk becoming "boys' clubs" where it is difficult for girls to spend time or seek services.

Privacy and Anonymity. One of the most common comments by staff at the centres was that the youth centre facilities were not optimal for the services offered, particularly in terms of privacy. One-room and small facilities, such as Ayaalolo, Wesley College, Mamfe Youth Centre, and YAS, Cape Coast, were inadequate in having space to offer counseling services alongside the other services offered, such as library or recreation. Staff at the small centres said that it was difficult to offer private counseling as facilities were only one room. At the Mamfe Centre, although three rooms were available, clinic and counseling rooms were only separated from the library by a small curtain that did not ensure auditory privacy. Young people noted that they want $\mathrm{RH}$ services that are both private and anonymous, so that they could seek services without being recognized for what they are doing. At Akropong, even though there is a room set aside for counseling, the layout required that walk through the small library facility to get to the clinic, which compromises anonymity of the services.

On the other hand, other facilities had adequate space and a structure that ensured privacy, as well as alternate routes to service rooms, allowing anonymity. Centres such as the Lartebiokoshie Centre, Adukrom, Teens' Centre, Kumasi and Abiriw have a comparatively better layout that allowed for private and fairly anonymous services.

Accessibility and Availability Accessibility and availability of services is fundamental to the effectiveness of youth centres. Issues such as publicity of the centres, clients' awareness of the services offered, hours and days of operation and availability of services are critical aspects of service delivery.

Location. The location of a given youth centre may have a strong influence on the patronage and services available. The youth centres situated at the Akropong

\footnotetext{
${ }^{5}$ Erulkar, Annabel, and Barbara S. Mensch, Youth Centres in Kenya: Assessment of Family Planning Association of Kenya's Youth Centre Programme, Nairobi: The Population Council, October, 1997.

${ }^{6}$ Glover, Evam Kofi, Angela Bannerman, Robert Miller, Heidi Jones, Eugene Weiss, and Joana Nerquaye-Tetteh, Adapting Reproductive Health Strategies to Adolescent and Youth Needs: Findings from Three Ghanaian Towns, paper presented at American Public Health Association (APHA), November, 1997.

${ }^{7}$ Erulkar, Amabel S., and Barbara S. Mensch, ibid., Phiri, Alford, and Annabel S. Erulkar, Zimbabwe National Family Planning Council Youth Centres: A Baseline Assessment, Nairobi: The Population Council, October, 1997.
} 
Teachers' Training College and the Wesley College, for example, are limited not only because the centres are unable to provide less than the full constellation of services, but also because these are fairly inaccessible to out-of-school youth. Out-of-school youth may not have the confidence to walk through the gates of the school premises. The girls especially find it embarrassing as they are required to report their destination to security personnel at the entrance to the colleges.

Most of the clients who came to the youth centres were in the vicinity of the centre. The majority of clients interviewed had walked to the centres $(85 \%)$ and $50 \%$ of clients had taken only 10 minutes or less to reach the centres. It appears that the centres service young people in the vicinity of the centres; few young people traveled long distances to visit the centres.

Publicity and Signboards. Most youth centres have a signboard with PPAG name and logo, as well as operating hours. Though the purpose of this is to publicize service availability, young people do not easily identify themselves and their concerns with sexual activity and family planning, as the PPAG logo connotes. The signboard is therefore stigmatizing to the target group - particularly the in-school youth who do not want to be associated with sexual activity. PPAG is currently spearheading a national youth logo for youth friendly services and programmes in Ghana, with the support of the National Population Council.

Other means of publicity of PPAG Youth Centres need to be found. Currently, word of mouth seems to be an important mechanism of publicizing the centres. Most youth that visited the centres had heard of them from their friends (46\%), while $21 \%$ heard about the centre from staff or volunteers, $12 \%$ from a teacher, and $9 \%$ from the signboard outside the centres. Fundamental to clients' access to service is basic awareness that services are available. Many of the clients at the youth centres were not aware that counselling and reproductive health services were available. Only $47 \%$ were aware that counseling was available and $50 \%$ of clients were aware that $\mathrm{RH} / \mathrm{FP}$ services were available.

Operating Hours. All the youth centres have similar opening hours, regular business hours from Monday through Friday, $8.30 \mathrm{am}$ or $9.00 \mathrm{am}$ to $4.30 \mathrm{pm}$ or $5.00 \mathrm{pm}$. Considering the primary target groups, such operating hours are rot convenient. Most school-going youth are in school during the day and out-of-school young people are working during business hours. Operating hours for youth centres need to be adapted to the special needs of young people. Programme activities should be extended to the weekends and early evening hours.

Service Availability Counseling and clinical services are not always available at the centres. Most professional staff are not permanently attached to one centre, but rotate between the youth centres in their regions. Centre staff said that young people were sometimes frustrated because they come for services when no service provider was on the premises or the time during which services were offered were not always reliable. As full-time clinical and counseling services are not possible, centres should post times during which the services will be offered so that young people know that they can come at a particular time and definitely receive services.

Management Information Systems (MIS) This assessment relied heavily on service statistics from the centres to review centre performance. The management information system (MIS) that was found at the centres were extremely weak. Each region, and even centres within the same region, all had different systems of recordkeeping and reporting. Different kinds of records were kept, with varying 
completeness and accuracy. For example, it was found that service providers were less likely to take background information on males that they served compared to females. Given the inconsistency in recordkeeping and the incompleteness of records, it was difficult to track performance across centres. At a minimum, centres need separate and integrated records for outreach activities and clinical/counselling activities. Information on clients such as age, sex, marital, and school status should be collected along with the information or service that was rendered. To the greatest extent possible, records should be designed so that they can be aggregated at the national level and across programme.

Community Involvement A number of centres were located in facilities donated by local organizations such as the Ministry of Health, the Presbyterian Church, and the Methodist Church. At times these arrangements constrained the programmes, such as limiting the provision of family planning (in Wesley College) and limiting use of the facility (in Ayaalolo). At the same time, these collaborations represent important, pioneering steps in involving other local organizations in youth programmes. Not only do they contribute to sustainability of programmes, but also extend the commitment to adolescent reproductive health beyond the walls of PPAG. Still, staff and volunteers often mentioned that more efforts need to be made to involve parents in youth programmes, as they were sometimes seen as a barrier to reaching young people.

\section{B. Youth Centre Staff}

Youth centre personnel are a critical component for effective programmes. Programmes require sufficient and accessible staff who are well-trained and knowledgeable, as well as non-judgemental.

Personnel Structure and Training. Staff and volunteers at the youth centres were split roughly evenly between salaried staff and volunteers, including peer promoters and those on attachment. Three quarters of the staff and volunteers had received training when they joined the centres. The quarter that had not received training were mostly students on attachment and peer educators. The programme relies heavily on non-professional volunteers. Nonetheless, programme managers need to ensure that these volunteers are adequately prepared to perform their duties at the youth centres. Though it was said that volunteers do not perform counseling, it is likely that young people will approach them for discussions, advice or contraceptives as these volunteers are easily accessible to youth. This assessment revealed that volunteers were slightly more conservative and judgmental in their views toward premarital sex and access to family planning methods than staff (see Counseling Skills). All staff and volunteers, regardless of whether they are counseling or non-counseling personnel, should be oriented and/or trained when joining the youth centres.

Reproductive Health Knowledge Staff and volunteers were asked a series of questions in order to assess their level of knowledge and preparedness to perform their duties in the youth centres. 
Table 3: Percentage of Staff/Volunteers with Correct Knowledge on Reproductive Health Issues, $\mathrm{N}=21$

\begin{tabular}{|c|c|}
\hline & $\%(n)$ \\
\hline Knew what to do if one forgets to take the pill one day. & $71 \%(15)$ \\
\hline Knew the most fertile period during the monthly cycle. & $76 \%(16)$ \\
\hline $\begin{array}{l}\text { Know that it is not dangerous for a girl under twenty to take oral } \\
\text { contraceptives. }\end{array}$ & $76 \%(16)$ \\
\hline $\begin{array}{l}\text { Know that it is possible for a girl to get pregnant if the boy withdraws } \\
\text { before ejaculation }\end{array}$ & $76 \%(16)$ \\
\hline $\begin{array}{l}\text { Know that a man cannot always tell if a woman has a sexually transmitted } \\
\text { disease. }\end{array}$ & $81 \%(17)$ \\
\hline $\begin{array}{l}\text { Know that if signs of a sexually transmitted disease disappear, it does not } \\
\text { necessarily mean the person is no longer infected with the disease. }\end{array}$ & $91 \%(19)$ \\
\hline Know that one can get HIV/AIDS through circumcision. & $91 \%(19)$ \\
\hline Know that a girl can become pregnant the first time she has sex. & $95 \%(20)$ \\
\hline $\begin{array}{l}\text { Know that condoms are effective protection against HIV/AIDS } \\
\text { transmission. }\end{array}$ & $95 \%(20)$ \\
\hline Know that oral contraceptives cannot cause deformed babies later on. & $95 \%(20)$ \\
\hline $\begin{array}{l}\text { Know that condoms do not have small holes that allow HIV to pass } \\
\text { through. }\end{array}$ & $95 \%(20)$ \\
\hline Know that one cannot get HIV/AIDS from mosquito bites. & $95 \%(20)$ \\
\hline Know that a girl can become pregnant if she has sex standing up. & $100 \%(21)$ \\
\hline Know that a healthy looking person can be infected with HIV/AIDS & $100 \%(21)$ \\
\hline Know that one cannot get HIV/AIDS by hugging a person with HIV/AIDS. & $100 \%(21)$ \\
\hline
\end{tabular}

Centre personnel were extremely knowledgeable on the reproductive health issues that were covered. Staff and volunteers were highly knowledgeable about HIV/AIDS and susceptibility to pregnancy, with virtually all staff and volunteers answering these questions correctly. A handful of staff and volunteers were not knowledgeable on the most fertile period during the monthly cycle, the safety and use of pills, or the dangers of withdrawal.

Opinions and Practices Staff and volunteers were read a series of statements regarding roles of men and women in society, adolescent sexual activity, and sexual violence. Table 4 displays the percent of staff and volunteers that held relatively liberal views regarding gender issues, sexuality, and violence. 
Table 4: Percentage of Staff/Volunteers with Equitable Attitudes on Topics, $\mathrm{N}=21$

\begin{tabular}{|c|c|}
\hline & $\%(n)$ \\
\hline $\begin{array}{l}\text { Disagree that sometimes a man rapes a woman when he cannot control } \\
\text { himself. }\end{array}$ & $14 \%(3)$ \\
\hline Disagree that girls who wear mini skirts are asking to be raped. & $81 \%(17)$ \\
\hline Disagree that sometimes when a girl says "no" to sex she means "yes." & $81 \%(17)$ \\
\hline Agree that emergency contraceptives are appropriate for unmarried girls. & $81 \%(17)$ \\
\hline Disagree that boys who have sex before marriage are bad. & $81 \%(17)$ \\
\hline Disagree that in some cases, a girl deserves to be raped. & $81 \%(17)$ \\
\hline Disagree that unmarried girls who have sex are bad. & $86 \%(18)$ \\
\hline $\begin{array}{l}\text { Disagree that the husband should decide how many children a couple will } \\
\text { have. }\end{array}$ & $86 \%(18)$ \\
\hline $\begin{array}{l}\text { Disagree that if money is scarce and the family cannot send all children to } \\
\text { school, boys should be sent before girls. }\end{array}$ & $95 \%(20)$ \\
\hline $\begin{array}{l}\text { Agree that women should have the same opportunities as men to hold } \\
\text { leadership positions in government. }\end{array}$ & $95 \%(20)$ \\
\hline Agree that girls who are menstruating can still play sports. & $95 \%(20)$ \\
\hline $\begin{array}{l}\text { Agree that boys that are in secondary school and having sex should be } \\
\text { allowed to use family planning methods. }\end{array}$ & $95 \%(20)$ \\
\hline $\begin{array}{l}\text { Agree that boys should be asked to spend as much time on household duties } \\
\text { as girls. }\end{array}$ & $95 \%(20)$ \\
\hline $\begin{array}{l}\text { Agree that girls in secondary school and having sex should be allowed to use } \\
\text { family planning methods. }\end{array}$ & $95 \%(20)$ \\
\hline $\begin{array}{l}\text { Disagree that a wife should not ask her husband to help with domestic duties } \\
\text { or childcare responsibilities }\end{array}$ & $100 \%(21)$ \\
\hline Agree that FLE should be taught in primary school. & $100 \%(21)$ \\
\hline
\end{tabular}

By and large, respondents held views that were gender equitable. Of all the issues that were addressed, staff and volunteers were more conservative regarding sexual violence. Rather than believing that rape is an act of violence and not an act of desire, most felt that men rape when they cannot control themselves, implying that rape is out of men's control in some cases. A handful of staff and volunteers felt that some girls deserve to be raped and that wearing mini skirts is an invitation for rape. Staff and volunteers need to reassess their views on violence against women as some seemingly hold views implying that girls or women should be blamed for rape and that men are not accountable for their actions.

Some staff / volunteers held double standards regarding boys and girls. While $71 \%$ $(n=15)$ felt that girls that become pregnant while in school should not be made to leave school, all respondents felt that boys who make girls pregnant should not be expelled.

Counseling Skills In order to assess the quality of counselling services, we asked staff and volunteers a series of questions presenting hypothetical situations and asking what they would say and do regarding the case presented. For example, we asked, "Suppose an unmarried girl who is 16 and in secondary school tells you about a situation. She has decided to have sex with her boyfriend and wants a family planning method. What would you say and do in this case?" and "suppose a girl who is 16 and in JSS tells you about a situation in her class where boys tease her by 
touching her breasts. What would you say and do in this case?"

In the first case, the girl in the scenario is unique in that she has planned for her first intercourse with a family planning method. Such contraceptive use during the first intercourse is highly correlated with effective use of family planning methods throughout life. Many counselors, said that they would attempt to dissuade the girl from having sex and provide family planning information and services only if the girl "insists." The responses below are typical of how youth centre personnel said that they would handle this case:

I will advise her against it by stressing the complications of early sex. I'll ask her to undertake other activities such as sports, games to overcome the desire and use up energy in her system. The last resort will be to prescribe condoms to be used by her friend. (Project Officer)

I will counsel her on abstinence but if she still insists on having sex, I will advise her to use the condom. (Project Assistant)

I will find out from her if she knows the consequences that will come after. I will also counsel her to abstain from sex since she is very young. If she did not agree with these then I will provide for family planning methods to her. (Project Assistant)

Counseling is a main component of PPAG's youth programme. Responses to these questions suggest that staff and volunteers advise young people, often letting their own biases influence that advice, rather than counsel them and allow them arrive at their own decision. Field staff and peer educators need additional training in counselling so that they can help individual young people arrive at decisions by themselves, rather than influencing those decisions.

Below are examples of responses to the scenario where a girl was being teased by boys at school who touched her breasts:

I'll discuss changes in growth with her. Help her understand desire and feelings that come up during the adolescent age and ask her to educate her peers and insist on them not making fun of her. (Project Officer)

If such a situation should happen, I will find out from the girl the way she behaves in the class and if possible, I will contact the school authority to have a lecture in that class to teach them how they should relate to each other. (Project Assistant)

I will ask her to examine herself if she has a particular behaviour that is contributing to that and tell her to inform her classroom teacher about it. (Project Officer)

That she should do everything possible to avoid the act of being touched. I'll then inform her that not having sex will not cause any harm to her body which having sex can. (Project Officer)

Though the majority of personnel suggested that the girl's classmates should be confronted and asked to stop the harassment, many respondents implied that this behaviour was normal by suggesting that it was a standard reaction to a girl's development. Others suggested that the girl was somehow to blame because of her behaviour. Only one counselor mentioned the rights of girls not to be harassed in such a way.

Some responses to the scenarios that we presented suggested that some counselors did not understand the concept of confidentiality. Many counselors said 
that, in certain situations, they would intervene with parents or other involved parties. Few mentioned that they would seek the permission of the young person before approaching others. Below is a selection of such responses to a scenario where a girl approached the counselor for an abortion:

\begin{abstract}
I will find out from her who impregnated her and who are her parents. So that we all come together and discuss the situation. Both parents from the boy's side and the girl's will be called to meet and discuss this problem. (Project Assistant)
\end{abstract}

As abortion is not legalized in this country, I will advise her to deliver and after continue her education. Her parents will be talked to. (Project Assistant)

Talk to the parents and ask their suggestion. Counsel the girl and let her know the choices and the consequences of the choice. (Project Officer)

Of the 291 youth centre clients interviewed, 55 (19\%) had received counseling from either a nurse or a counselor. We asked these clients a series of questions regarding their perceptions of the counselor and of the session (Figure 1,2). The vast majority of clients found the counselor understanding and sympathetic. Importantly, most $(95 \%)$ felt that the counselor will keep everything that was discussed confidential. However, a significant proportion found the counselor embarrassed (27\%) and judgmental (43\%). Most clients understood everything that the counselor had to say, but many had more questions for the counselor that remained unasked $(22 \%)$, issues that remained undiscussed (27\%), and $36 \%$ of clients would have liked more time with the counselor.

\title{
<INSERT FIGURES 1, 2 APPROXIMATELY HERE>
}

These results indicate that staff need some more training on counseling. Indeed, when staff were asked what additional training they required, counseling was the most common felt need. Staff/volunteer responses to questions on counseling reflected that counseling staff are not able to remain neutral and non-judgmental during the counseling process. This suggests that staff need to clarify and harmonize PPAG's stand on how to handle matters affecting young people such as the need for family planning services and sexual harassment. Staff need to understand the concept of confidentiality.

Secondly, staff should take a "no missed opportunity" approach by counselling on reproductive health issues even when young people present with non- $\mathrm{RH}$ problems. For this assessment, we reviewed the case records of counselors. The majority of youth presented with problems that were social in nature (see Appendix for extracts of cases presented for counseling). While staff obviously counsel young people on the problem that they present, they should also take the opportunity of the intimate counseling environment to discuss sexuality and reproductive health with the adolescent.

\section{Youth Centre Clients}

Profile of Youth Centre Clients. In order to give a sense of the youth visiting the centres, all clients that visited the youth centres for any reason were interviewed and, where the volume of clients was large, clients were selected at random for interview. Clients interviewed were roughly equally divided between boys and girls. Gender balance at the centres differed from centre to centre. Akropong and Mamfe centres were dominated by boys ( $78 \%$ of those interviewed), while virtually all visitors to Abiriw were female (98\%). Client ages ranged from 9 to 41 years with an average age of 18 . 
Ninety-five percent of youth visiting the centres were within the target age group of 10 to 24 , suggesting that the centres are doing a good job of attracting the intended target.

The centres are attracting a good balance of the in- and out-of-school. Sixty percent of clients were in-school, while $40 \%$ were not. Fifteen percent had achieved less than Junior Secondary School (JSS); 44\% had attained the JSS level, while 30\% had reached the secondary level.

The vast majority (87\%) were unmarried, another $10 \%$ were married or living with a partner, and $3 \%$ were separated, divorced or widowed. Among those that had ever been married or cohabitating, the majority were girls (64\%). Twenty-eight percent $(28 \%)$ of the clients had at least one child, with $80 \%$ of these being female. A minority of youth lived with both natural parents (41\%). Twenty-six percent (26\%) lived with just one parent while $29 \%$ lived with other relatives or non-relatives, and $3 \%$ lived alone. Twenty-three percent of visitors to the youth centres said that they had ever used family planning methods.

Reason for Visiting the Centres Library facilities seem to be an effective mechanism to draw young people to the centres. Most of the clients that were interviewed came to the youth centre to use the libraries (42\%). Seventeen percent (17\%) came for counselling, $15 \%$ came for recreation or to meet friends, and $6 \%$ came for $\mathrm{FP} / \mathrm{RH}$ services. We asked clients to name the reasons that they had come to the centres for all the times they had used the centres (Table 5).

Table 5: Percentage of Youth Having Visited the Centres for Various Reasons ${ }^{8}$, by Sex of Client

\begin{tabular}{|c|c|c|c|}
\hline Reason & $\begin{array}{c}\text { Males } \\
(n=146)\end{array}$ & $\begin{array}{c}\text { Females } \\
(n=142)\end{array}$ & $\begin{array}{c}\text { All Clients } \\
(\mathrm{n}=288)\end{array}$ \\
\hline Library & 76 & $47^{\star \star \star}$ & 62 \\
\hline Recreation & 53 & $32^{\star \star *}$ & 42 \\
\hline Counselling & 36 & 35 & 35 \\
\hline Family Planning Services & 5 & $23^{\star \star \star}$ & 14 \\
\hline Other RH Services & 8 & $16^{*}$ & 12 \\
\hline
\end{tabular}

While library and recreation are very effective mechanisms to draw young people to the centres, they are more effective for boys than for girls. Boys were significantly more likely to use the centres for these reasons than were girls. Importantly a significant proportion of young people had come to the centres at one time for counselling, suggesting that the centres have been successful in publicizing these services in the centres. Family planning and $\mathrm{RH}$ services were less popular reasons for visiting the centres, with significantly more girls seeking these services than boys.

Reproductive Health Knowledge of Youth at the Centres We asked young people at the centres a series of questions on reproductive health and family planning in order to understand their level of knowledge and where youth centre staff need to concentrate educational efforts (Table 6).

Table 6: Percentage of Youth with Correct Knowledge on Reproductive Health Issues

\begin{tabular}{|c|c|c|}
\hline $\begin{array}{c}\text { Males } \\
(n=146)\end{array}$ & $\begin{array}{c}\text { Females } \\
(n=142)\end{array}$ & $\begin{array}{c}\text { All } \\
(n=288)\end{array}$ \\
\hline
\end{tabular}

\footnotetext{
${ }^{8}$ Vocational training is offered only at the Abiriw Centre, and so is not included in this analysis.
} 


\begin{tabular}{|c|c|c|c|}
\hline $\begin{array}{l}\text { Knew period during the monthly cycle when a girl is most likely to } \\
\text { get pregnant. }\end{array}$ & 20 & 28 & 24 \\
\hline $\begin{array}{l}\text { Agreed that it is possible for a girl to get pregnant if the boy } \\
\text { withdraws before ejaculation }\end{array}$ & 44 & 44 & 44 \\
\hline $\begin{array}{l}\text { Disagreed that it is dangerous for a girl under twenty to take oral } \\
\text { contraceptives. }\end{array}$ & 54 & 41 & 48 \\
\hline $\begin{array}{l}\text { Disagreed that oral contraceptives can cause deformed babies later } \\
\text { on. }\end{array}$ & 56 & 50 & 53 \\
\hline Agreed that one can get HIV/AIDS through circumcision. & 65 & 55 & 60 \\
\hline $\begin{array}{l}\text { Disagreed that condoms have small holes that allow HIV to pass } \\
\text { through. }\end{array}$ & 70 & $53^{\star \star *}$ & 62 \\
\hline $\begin{array}{l}\text { Disagreed that a girl cannot become pregnant if she has sex } \\
\text { standing up. }\end{array}$ & 69 & 59 & 64 \\
\hline Disagreed that one can get HIV/AIDS from mosquito bites. & 73 & $55^{\star * *}$ & 65 \\
\hline $\begin{array}{l}\text { Disagreed that a man can always tell if a woman has a sexually } \\
\text { transmitted disease. }\end{array}$ & 73 & 61 & 67 \\
\hline $\begin{array}{l}\text { Disagreed that if signs of a sexually transmitted disease disappear, } \\
\text { it means the person is no longer infected with the disease. }\end{array}$ & 70 & 69 & 69 \\
\hline $\begin{array}{l}\text { Disagreed that a girl cannot become pregnant the first time she has } \\
\text { sex. }\end{array}$ & 73 & 69 & 71 \\
\hline $\begin{array}{l}\text { Agreed that condoms are effective protection against HIV/AIDS } \\
\text { transmission. }\end{array}$ & 84 & 73 & 79 \\
\hline Agreed that a healthy looking person can be infected with HIV/AIDS & 83 & 79 & 81 \\
\hline $\begin{array}{l}\text { Disagreed that one can get HIV/AIDS by hugging a person with } \\
\text { HIV/AIDS. }\end{array}$ & 81 & 82 & 82 \\
\hline Aggregate RH Knowledge Score (Mean Score) & 8.3 & $7.5^{\star}$ & 7.9 \\
\hline
\end{tabular}

Differences between boys and girls significant at: ${ }^{*} p<0.05{ }^{* *} p<0.01{ }^{* * *} p<0.001$

Young people in the centres were not extremely knowledgeable on reproductive health issues. Very few (24\%) knew the period during the monthly cycle when a girl is most likely to get pregnant. Fewer than $50 \%$ knew that withdrawal could still cause a pregnancy and that oral contraceptives are safe. We constructed an aggregate score for each respondent reflecting the number of correct responses on the RH questions. Out of a total of 14 questions, young people averaged only 8 questions correct, with boys significantly more knowledgeable than girls. Most young people (94\%) could name at least one family planning method, with the majority of young people mentioning the condom (86\%). After condoms, clients named pills $(64 \%)$, injectables (34\%), foaming tablets (31\%), and IUCD (17\%).

Youth who come to the centres are seriously deficient in reproductive health knowledge. Centres must make greater efforts to reach young people with reproductive health and family planning information and take on a "no missed opportunity" approach, using any forum to convey such information. 


\section{Utilization Of Clinical Services}

The volume of clients coming for RH/FP information and services at the youth clinics was reviewed for the 21 months previous. In all 988 clients had received services at the five centres with clinics (Akropong, Abiriw, Mamfe, Adukrom, and Teen Clinic, Kumasi). A fairly large volume of clients visited the youth centres, particularly in the Teen Clinic - Kumasi where performance at the clinic was similar to a busy mainstream family planning clinic (Figure 3). Performance of the clinics varied significantly. Table 7 displays the average number of clients seen in a month at the clinics.

<INSERT FIGURE 3 APPROXIMATELY HERE>

Table 7: Average Number of Clients Seen per Month at Youth Clinics, 1/97 to 9/98

\begin{tabular}{l|c}
\hline Clinic & $\begin{array}{c}\text { Average Number of Clients } \\
\text { Seen per Month }\end{array}$ \\
\hline Teens' Centre, Kumasi & 52 \\
\hline Akropong Teachers Training College & 16 \\
\hline Adukrom & 13 \\
\hline Abiriw & 8 \\
\hline Mamfe & 6 \\
\hline
\end{tabular}

Not all the clinic clients fell within the target age group (age 10 to 24) and at several clinics a significant number of clients fell outside the target age group (Figure 4). Overall, $43 \%$ of clients at the youth centre clinics were over 24 years of age, which is out of the target age group. The vast majority of clients that came for $\mathrm{RH} / \mathrm{FP}$ services were female (89\%). Figure 5 reveals the distribution of male and female clinic clients at the centres.

$<$ INSERT FIGURES 4, 5 APPROXIMATELY HERE>

The majority of clients came to the clinics for FP services and for $\mathrm{RH}$ counseling and information. Youth were less likely to come for family planning services compared to those outside the target age and more likely to come for $\mathrm{RH}$ counseling and information (Figure 6)

<INSERT FIGURE 6 APPROXIMATELYHERE> 


\section{RECOMMENDATIONS}

PPAG's youth centres are well designed and well performing. Staff and volunteers were extremely knowledgeable on reproductive health $(\mathrm{RH})$ issues and PPAG had made important efforts to promote partnerships in its youth programmes. Below are the recommendations that arose from this assessment:

- Within the youth centres, separate rooms are necessary for recreational facilities, lecture rooms, library, counseling, and clinical services to ensure privacy. Rooms need to be located in such a way that young people can access counseling and clinic rooms with relative anonymity

- The centres' signboards should be replaced with the youth friendly logo which is currently under development by PPAG. In addition, youth centres should be marketed both in the print and electronic media as youth friendly to encourage greater patronage.

- Hours and days operation should be adapted to the lifestyles of young people. Centres should be open during early evening hours and on weekends. The centres should consider closing during the early morning weekday hours when young people are normally engaged in other activities.

- Centres need to have consistent staff who are available at all times to offer services. Each centre should have at least one full-time community health nurse in addition to the project office of the centre.

- The recordkeeping systems at the centres need to be improved and harmonized At a minimum, centres need separate and integrated records for outreach activities and clinical/counselling activities. Information on clients such as age, sex, marital, and school status should be collected along with the information or service that was rendered. Where possible, the MIS should be computerized. There is need for secretarial equipment such as computers and photocopiers to support these activities.

- PPAG has made laudable efforts to involve the community and other stakeholders in its youth centre programme. PPAG should continue to promote community involvement and commitment through soliciting for further donations, both in the public and private sector. Additional efforts need to be made to reach out to parents.

- Additional efforts should be made to train or orient volunteers, even if they are simply on attachment for a short period. PPAG relies heavily on volunteers in the programme. While volunteers are not expected to perform counseling, it is likely that youth will approach them as they are relatively accessible.

- Staff and volunteers require further training on counseling and sensitization on gender issues. While staff and volunteers were extremely knowledgeable on $\mathrm{RH}$, they were found to advise, rather than counsel and many were not clear on the issue of confidentiality. In addition, some staff/volunteers held conservative attitudes toward violence against women.

- The youth centres are attracting a good balance of boys and girls within the target 
age group, 10 to 24 . However, a significant proportion of those coming to the centre for clinical services are out of the target age and he vast majority are female. Only about half of the youth centre clients were aware that counseling and clinical services were available. The centres need to reach out to their existing clientele to inform them of available services. Also, PPAG needs to ensure that its clinics are not dominated with older clients which defeats the purpose of having a clinic dedicated to youth.

- Youth centres need to intensify RH education to its existing youth centre clients. Clients were found to be seriously deficient in $\mathrm{RH}$ knowledge. The centres need to integrate $\mathrm{RH}$ information in all activities at the youth centres so that, no matter what a young person comes to the youth centres for, he/she leaves with heightened understanding of $\mathrm{RH}$-related issues.

- Facility equipment should be improved or added including IEC equipment and laboratory equipment. 


\section{Appendix I: Counselling Cases}

Below is sample of counselling cases seen by PPAG staff. Text is taken directly from the records of centre counselors. Problems presented by boys are different than those of girls. The cases below demonstrate the cases presented are complex and multi-dimensional. Youth centre staff need to be well equipped to deal with such complexities that young people face.

\section{$\underline{\text { Girls' Cases }}$}

She expresses displeasure at entry into marriage at her age. She wanted to further her education and learn a trade after school. Moreover she has lost interest in the man she had her baby with since he is far older than she. She also wants the man to remit the child regularly. (Girl, aged 17).

A man wants to marry her and help her to learn a trade. But she wants her nursing child to start schooling before marrying. Wants to learn her skill training in Accra so as to stay with the man who has proposed to marry her. (Girl, aged 20)

Wants to take legal action against the man who has refused responsibility of her baby. (Girl, aged 17)

[She is a] drop out from school because there was no one to pay her school fees because of broken home. [She] wants to contact the father to plead whether he could help her learn dressmaking. Father wants her to wait for about two months of which he will be able to pay for the cost involved in the school training. (Girl, aged 20)

Her father disliked the boy who impregnated her so he did not allow the boy to come forward to accept the pregnancy. (Girl, aged 20)

She claims her father is a pagan. She goes to church and the father does not agree with her at all and, as such, does not want to assist her in anything concerning her skill training. (Girl, aged 17)

[She] wants to know why we have menstrual pains and what to do about it. (Girl, aged 13)

Although her boyfriend maintains her, [she] wanted him to perform the necessary customary rites of marriage which he had failed to perform. (Girl, aged 21)

\section{Boys' Cases}

Girlfriend claims she is pregnant. [He] thought it was not true because he uses condoms whenever having sex with her. (Boy, aged 21)

His parents have broken up and the father who is the breadwinner has lost his job and can't cater for him - his schooling and registration (Boy, aged 16)

He was smoking and confronted by teacher so had stopped school (Boy, age unknown)

Wants to know about how to deal with pressures about sex and money (Boy, aged 18) 
He couldn't register for the final SSS exams because the parents couldn't pay for his fees. He is very worried because he thinks his future has been shattered but still wants to continue in school (Boy, aged 17) 